\title{
The Effect of Electronic Word of Mouth on Twitter towards Customers' Purchase Intention at Starbucks Coffee Indonesia
}

\author{
Wijayanti D.P ${ }^{1}$, Vienna Artina $S^{2}$, Maria Angela ${ }^{3}$ \\ ${ }^{1,2.3}$ Sekolah Tinggi Pariwisata Trisakti, Jakarta, Indonesia \\ E-mail: ${ }^{1 .}$ Wijayanti@stptrisakti.ac.id and ${ }^{2 .}$ viena.artina@stptrisakti.ac.id
}

\begin{abstract}
Internet has been growing rapidly in Indonesia. Starbucks is one of the companies which adopts Twitter as a media to promote its products since interactions occurred in the social media might result in Electronic Words of Mouth (eWoM) with larger and faster range of broadcasting rather than Words of Mouth (WoM). EWoM might bring positive and negative impacts towards customers purchase intention. This research is also expected to provide brief description on to what extent is the effect of eWoM towards customers' purchase intention for Starbucks Coffee Indonesia, therefore it can give significant input on the most effective marketing system. Therefore it can be concluded that the relation among variables are intermediate, the most dominant sub-variables in determining customers purchase intention is psychological factors with average score of 3.31. The factors in between are personal factor with 3.55 , and cultural factors with 3.61. It can be summarized that eWoM on Twitter affects in customers purchase intention. This means that customers seek information from Twitter to find out information regarding the counter. Positive eWoM will eventually encourage customers to buy the produts, while negative $\mathrm{eWoM}$ will also decrease the purchase intention.
\end{abstract}

Keywords-Electronic Words of Mouth (eWoM), Twitter, Customer, Purchase Intention, Starbucks Indonesia

\section{INTRODUCTION}

In this era of globalization, communication, both informal and marketing, is mostly done through social media. According to Kaplan and Haenlein (2010), social media is a group of internetbased applications that build on the foundation of Web 2.0 ideology and technology, and which enables creati on and exchange of user-generated content. Paquette (2013) also argues that social media has evolved from a medium as a means of connecting family and friends, becoming a street seller can enlarge their marketing network to a wide range of consumers.

Kaplan and Haenlein (2010: 60) argue that through social media, a company can promote a product and form an online community or group for consumers who love the brand used. The existence of an online community or group will allow for an electronic social interaction that will lead to electronic word of mouth (eWoM).

According to Henning-Thurau (2004: 39) Electronic word-of-mouth (eWoM) is a positive or negative statement made by potential, actual, or former customers about a product or company, made available to many people and institutions via the Internet. After seeing a lot of evidence about the power of social media and its impact on electronic word of mouth, companies are starting to pay attention to social networks and online communities that can become an important new resource for the company. One such company is Starbucks. Starbucks is a coffee company and a global coffee shop network from the United States headquartered in Seattle, Washington.

Based on the 2013 Survey, Starbucks is the world's largest coffee shop company with 20,336 stores in 61 countries. The Starbucks coffee shop opened its first store at Plaza Indonesia on May 17, 2002. In Indonesia, the Starbucks franchise is held by PT Sari Coffee Indonesia, one of PT Mitra Adiperkasa Tbk(MAP) subsidiaries. Currently, Starbucks has 188 outlets throughout Indonesia, and plans to open 35 more outlets by 2015 (CNN Indonesia, 10).

Starbucks Indonesia has two active social media accounts through Twitter. The social 
media accounts are administered by an active admin, where they answer consumer questions and conduct regular marketing. Electronic word of mouth (eWoM) is a bit different from traditional word of mouth, where eWom has a much larger broadcasting and speed scale than WoM, more accessible, measured, observed and more permanent. While WoM, according to Cheung and Lee (2012) is the sharing of information occurs in sync in small groups.

Research by Williams and Buttle $(2014 ; 1)$ finds word of mouth to have a profound impact on the effectiveness of a company. Word of mouth affects consumer buying and loyalty. However, this can also negatively impact the word of mouth to be greater than the positive impact if the message spreads negatively among consumers.

Chevalier and Mayzlin (2006: 345) also said that eWoM messages become an important means for consumers to get information about product quality and service quality. Based on the Chatterje journal (2001: 129), eWoM is also effective in reducing the risks and uncertainties that consumers experience when buying a product or service, so buying interest and consumer purchase decisions can be affected.

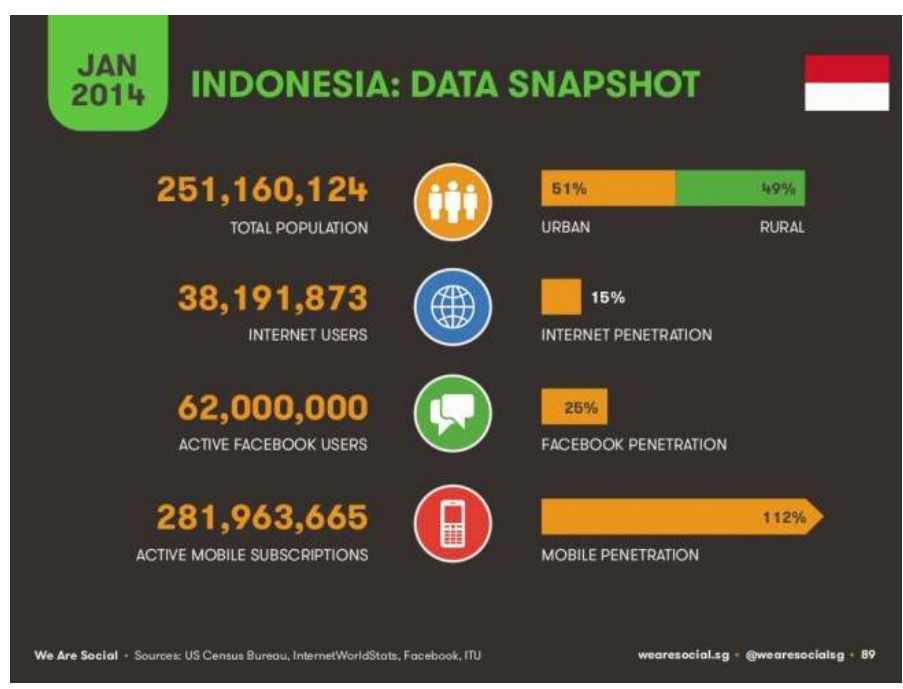

FIG 1. INTERNET PENETRATION AND SOCIAL MEDIA IN INDONESIA Source: GlobalWebIndex Wave 11 by wearesoscial.sg

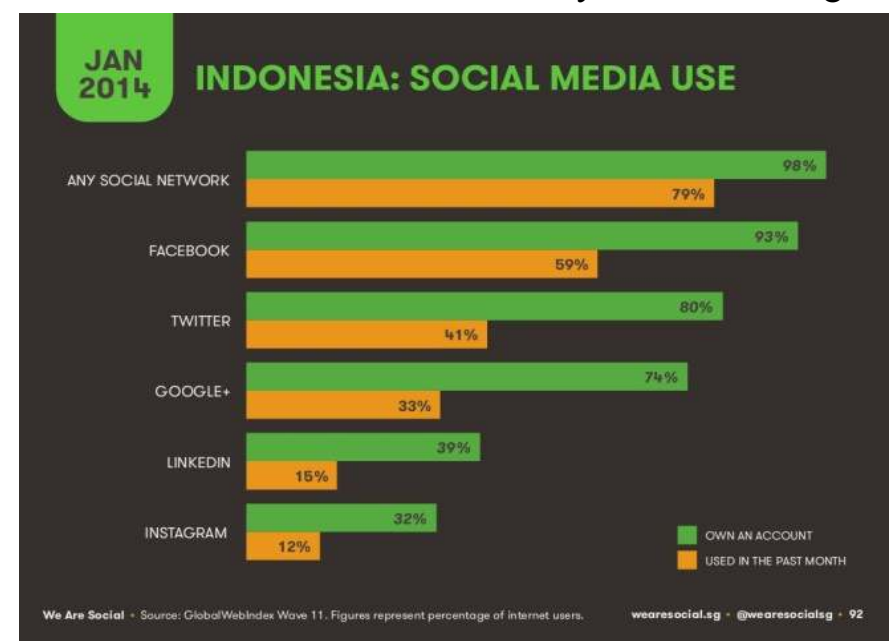

FIG 2. INTERNET USE AND SOCIAL MEDIA IN INDONESIA

Source: GlobalWebIndex Wave 11 by wearesoscial.sg 


\section{LITERATURE REVIEW}

\section{A. Word of Mouth}

Based on the Cambridge Business English Dictionary (2011), word of mouth means the process of notifying a product or service to people who are known, usually because consumers think that the product or service has a good quality and want to influence others to try it too. Word of mouth is certainly one method of communication orally. Oral communication is a big part of human life, can be seen from the number of folklore that affect the behavior of each person. If used commercially, this is called word of mouth marketing. The reverse is Proconsumer WoM, which is motivated by a person or organization that does not make a profit.

In marketing, word of mouth in the opinion of Dichter (1966), involves the dissemination of information between non-commercial communicators (non-recipients) and recipients related to brands, products, or services. Word of mouth marketing is done through social media called Social Media Marketing.

\section{B. Social Media Marketing}

Trattner and Kappe (2013) say that social media marketing is the process of getting active visitors on the web or attention through social media sites. In social media marketing, marketers will try to make the content as attractive as possible in order to attract readers' attention through their respective social media. To attract this attention will be required a good promotion, so that consumers will, with their own will, indirectly become a means of product promotion.

Social media marketing is done through social media. Social media allows an individual to interact with each other and build closer relationships. Thus, when a company creates a social media account, consumers can be invited to interact directly. Such interactions can become more personal to the consumer than commercials.

\section{Electronic Word of Mouth (eWoM)}

The definition of eWOM according to Henning-Thurau, Qwinner, Walsh, and Gremler (2004) is any positive statement made by customer about the quality of the product.

\section{TABLE 1 : EWOM PLATFORM}

\begin{tabular}{ll}
\hline \multicolumn{1}{c}{ Platform } & \multicolumn{1}{c}{ Example } \\
\hline Online discussion forums & Kaskus \\
Consumer review sites & TripAdvisor \\
Weblogs & Live Journal, Word Press \\
Social network sites & Facebook, Twitter, Tumblr, Path \\
Shopping sites & Amazon, Ebay, ThinkGeek, LootCrate
\end{tabular}

Source: Cheung dan Thandani (2012)

\section{Electronic Word of Mouth In Social Media Twitter}

One form of dissemination of information popular through social media in recent years is through microblogging. Microblogs, based on the opinions of Kaplan and Haenlein (2010), are a form of blog that allows users to share content on a small scale such as short text (usually less than 200 characters), images, photos, and video links. The content may be viewed by everyone or a specific group chosen by that user. One of the famous microblogging sites is Twitter, which is based on posting on their blog a 5. eWoM factor Based on the journals by Tseng and Hsu 
(2010), there are several important factors in determining eWOM, namely

- Seeker's level of expertise (ES)

Bansal and Voyer (2000) say that the level of expertise of information seekers is the most important thing that will determine the resistance of a person to an affected. The study says that the level of information seeking expertise will influence the word of mouth given by someone who recommends a product or service. Herr, Kardes, and Kim (1991) say that if the information seeker's ability tends to be high, then he will be more unaffected by the opinions of others.

- Recommender's level of expertise (ER)

The expertise of a recommender has been said in Herr, Kardes, and Kim (1991), as an important factor in determining one's buying interest. There is also an opinion from Gilly (1998) which states that there is a positive relationship between product knowledge and experience in information retrieval.

- Trust

Trust is important in communication, especially in the spread of word of mouth. In social interaction, trust is one of the main factors, as said by Lin, Weng, and Hsieh (2003). Based on the opinions of Petty and Cacioppo (1986) and also McCole, Ramsey and Williams (2009) trust means that information sources are considered reliable and reliable by the recipient of the information. In addition, previous research by Wangenheim and Bayon (2004) has determined that trust influences the perceptions and opinions of recipients of information when the recipients have specific knowledge or expertise about the product.

- Information Quality (IQ)

When consumers buy products, they have a tendency to gather all the information. Of the many information collected, consumers will certainly believe only a few parts that he deemed to be quality and reliable information. This suggests that there is a significant relationship between trust and quality of information, as has been observed by Rieh (2002) and also Cheung, Lee, and Rabjohn (2008).

- Perceived Influence (PI)

Perceived influence means the perceived influence of the consumer or the information seeker about the product. This influence usually comes from information that can be or from recommendations that are trusted by consumers. According to Herr, Kardes, \& Kim (1991), the higher the skills and knowledge of information seekers, the more they are less affected by the recommendations or information from outside.

\section{E. Technology Acceptance Model}

In measuring the influence of a technological development, it can be done by looking at the Technology Acceptance Model (TAM) by Davis (1989). TAM is an information system model that determines how consumers receive and use technological developments. This model shows that when users are presented with new technology, a number of factors will influence their decision about how and when they will use them, especially:

- Perceived usefulness (PU)

This is defined by Davis as "the extent to which a person believes that using a particular system will improve his performance or work," or perceived benefits.In this study, MPW can be used to see the extent to which consumers believe eWOM is useful for improving ease in purchasing products.

- $\quad$ Perceived ease-of-use (PEOU)

Davis defines this as "the extent to which one believes that using a particular system will be free from hard work," which in this study can be used to examine the extent to which consumers believe that with eWOM consumers will find it easier to find information on products. 


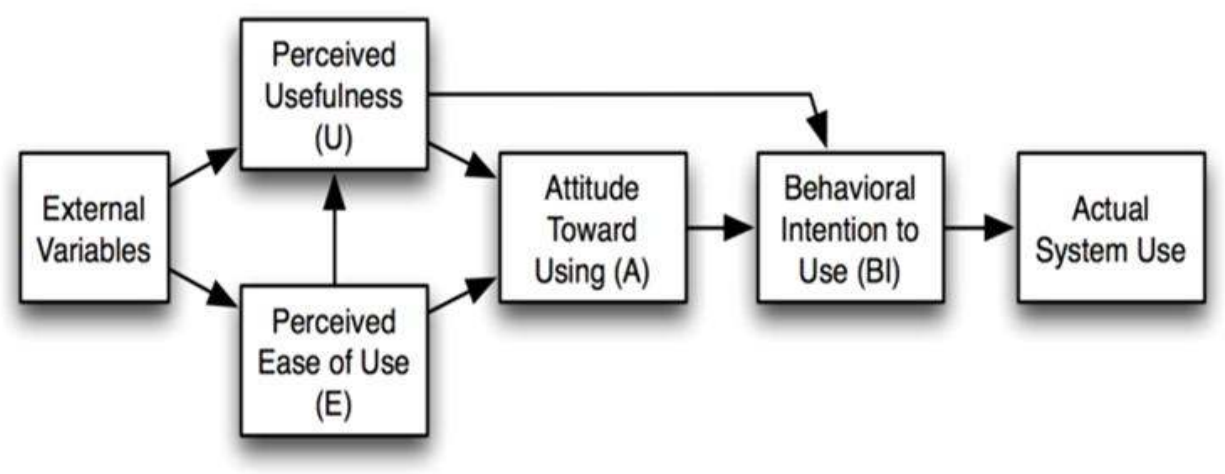

Fig 4.Technology Acceptance Model

Source: Perceived usefulness, perceived ease of use, and user acceptance of information technology, MIS Quarterly September by Fred D. Davies (1989).

- Perceived Enjoyment (PE)

Davis (1992) added Perceived Enjoyment to the TAM he created earlier. PE is added as additional motivation for acceptance of a product. In PE measurements, it will be seen how much consumers feel the pleasure in the use of technology (in this research is social media), because enjoyment is a major factor in one's interest to use technology.

\section{METHODS}

The research approach is quantitative approach, it is used to examine the population or a particular sample, where in general the sampling technique is done randomly, data colle ction using research instrument, quantitative data analysis.

In this study, researchers will examine the eligible individuals in the study, individuals who are followers of Twitter@SbuxIndonesia account, where the followers have been exposed to eWoM information about Starbucks products and have or are currently domiciled in Jakarta. So, what is being studied is electronic word of mouth and buying interest from the consumer. In this study, the population is a follower of Twitter Starbucks Indonesia. With a total of 834,000 on 15 May 2015.

\section{RESULT AND DISCUSSION}

\section{A. Demographic Data}

1. Data of Respondents by Sex

The highest percentage of respondents are women with a presentation of $81 \%$. Based on these results can be concluded that women more and more often use social media, is also more receptive in interacting with people who have not previously known through the internet / social media. In addition, men are more likely to choose another coffee shop that significantly sells coffee cheaper than Starbucks.

\section{Respondent Data by Area of Residence}

It is known that the highest percentage of respondents came from Jakarta with $84 \%$ percentage. Based on these results it can be concluded that the use of internet and social media is higher in Jakarta than outside Jakarta. In addition, it can also be due to the location of many more Starbucks stores in Jakarta than outside Jakarta.

\section{Data of Respondents by Age}

The percentage of respondents most aged around 21-25 years as much as $36 \%$. Based 
on these results it can be concluded that Starbucks products are consumed more by respondents with younger age. This can be due to the location of a Starbucks store that is usually located in a location close to the university or offices. Also, the younger generation tends to be more receptive to new product creations that Starbucks always does. In addition, the age of 21-25 years is the age where the use of social media is a popular choice for socializing. Age 35-40 years has the lowest percentage of 3\%, because at that age, respondents are busier working and do not have a high interest in social media.

\section{Data of Respondents by Type of Work}

The highest percentage of respondents comes from the students with $42 \%$ percentage. As has been previously concluded, this can be due to the location of a Starbucks store that is usually located in a location close to the university.

\section{Data of Respondents by Revenue}

The highest percentage of respondents has income with a range of less than 1 million as much as $45 \%$. With the age range of consumers who tend to be young, where most consumers come from among students and second most of the students, it is concluded that Starbucks consumers tend to have low income. Where the income is obtained most of the money pocket or part-time work.

\section{Data Respondents based on Frequency Use Twitter}

The highest percentage of respondents as much as 39\% using social media Twitter every day. Respondents who regularly use social media Twitter will follow multiple Twitter accounts actively, one of which is @ SbuxIndonesia account. With so many respondents using Twitter, disseminated promotions will reach a sizable consumer target.

7. Respondents Data Based on Frequency of Visit to Starbucks Store

The highest percentage of respondents come regularly to Starbucks outlets with monthly frequency of $47 \%$. This can be due to the price of expensive Starbucks products and Starbucks promotions, usually monthly or monthly, making consumers who, though active followers of @SbuxIndonesia's account, will limit product purchases.

\section{B. Data Variable X (Electronic Word of Mouth)}

\section{Level of Information Seeking Skill}

There are 39\% of respondents agree that they know the products sold by Starbucks. From this result it can be concluded that most consumers who buy Starbucks products have known what they will buy before. As many as 5\% strongly disagree, which means a small percentage of consumers do not know which products to buy before, because they are not so concerned about the product or are new customers.

2. Recommender's Expertise

There are 39\% of respondents agree that the admin of the @SbuxIndonesia or consumer account with a tweet whose opinions are retweeted by the admin have a good product knowledge or promotion Starbucks. Good knowledge means the admin is a competent employee who can improve the company's image. As many as $4 \%$ strongly disagree that the admin does not have the appropriate knowledge, which these consumers feel they have more knowledge about coffee products and other foods and beverages sold.

\section{Trust}

There are 39\% of respondents agree that they believe in the opinion or promotion provided by admin@SbuxIndonesia or consumers whose opinions are retweeted by admin. With a high sense of confidence, it will be the higher the possibility of them buying products promoted via Twitter. As many as $8 \%$ strongly disagree, which means they are more confident in their opinions and tastes than others.

\section{Quality of Information}

There are $40 \%$ of respondents agree that when they see promotions from admin or other 
consumer opinions via Twitter, it will affect them in buying Starbucks products. 13\% strongly disagree, it can be because they have opinions and stances that cannot be influenced in purchases a product.

\section{Ease of Use}

There are $37 \%$ of respondents agreed to the benefits of being a followers @ SbuxIndonesia account, because the tweets provided contain information required by consumers concerned. As many as 7\% strongly disagree because they feel the @S SbuxIndonesia account has no significant benefits when they will buy Starbucks products.

\section{6. $\quad$ Perceived Benefits}

There are $40 \%$ of respondents agree that by looking at tweets provided by the admin or other consumers, the purchase of a product becomes facilitated because they already know about the product before. A total of $11 \%$ strongly disagree, because that with all the information distributed, they do not feel eased and still have to rely on their own opinions when purchasing the product.

\section{Perceived Pleasure}

There are $36 \%$ of respondents gave a positive answer that they enjoy the use of social media Twitter compared with other social media usage. While as many as $14 \%$ of respondents stated that they strongly disagree and prefer other social media on the grounds that Twitter is no longer the most popular social media. as many as $45 \%$ of respondents agreed that they enjoyed both the information and promotions distributed via Twitter, or the interactions made by admin @SbuxIndonesia as they answered questions, responded to complaints, or retweeted their tweets about Starbucks products.

\section{Data Variable Y (consumer buying interest) \\ 1. Cultural}

There are $36 \%$ of respondents agreed that their culture has an effect on when they make apurchase, both ethnic culture and national culture. While $22 \%$ strongly disagree, because for them, culture is not an important thing. as many as 35\% of respondents approved Starbucks as a beverage consumed by a high social class, due to its fairly expensive price and many locations in the mall. $6 \%$ strongly disagree, because they feel that Starbucks consumers are people who come from various circles.

\section{Social}

There are 33\% agreed that the opinions of their family members influenced their decision in purchasing a product. A total of $28 \%$ disagreed with this opinion, because that they would consume the products they wanted at the time and rely on their own opinions rather than others. as many as $42 \%$ agree that they will be affected by purchases made by their friends when going to make a purchase. As many as 16\% strongly disagree, because they are not easily influenced by the opinions of others, and prefer to try a product first rather than directly follow the opinions of others.

\section{Personal}

There are 36\% agree that the price of products sold by Starbucks tends to be expensive, most argue that the taste of the product, especially coffee, is not much different from some of the other lower-priced coffee shops, but they still buy Starbucks products due to innovations and places comfortable. A total of 9\% strongly disagree, where they are regular Starbucks consumers and feel the price offered is comparable to the places and services provided. as many as $40 \%$ agree that buying and consuming Starbucks products, or rather buying coffee innovations and "hanging out" at Coffee Shop is a popular trend today. As many as $7 \%$ strongly disagree, where respondents argue that Starbucks is a trend that has passed its time.

There are 4\% agree that the work they have will affect their purchasing decisions. Popular opinion is, with high salaries, then they will be able to consume products more often. As many as $7 \%$ 
strongly disagree, where respondents argue that the type of work someone does will not affect the Starbucks products they will buy, although they still feel that the salary will have a significant effect.

There are $34 \%$ agree that Starbucks products can be consumed by people of all ages, because many Starbucks products do not contain coffee and consumers may ask not to use too much sugar / cream so that small children and parents can consume the product. However, as many as $17 \%$ strongly disagree, where they think that the materials or calories contained in Starbucks products are not suitable if consumed by small children (approximately under 12 years) or parents (approximately over 50 years).

\section{Psychological}

There are $42 \%$ agreed they would follow their religious rules in buying and consuming a product. This is because Indonesia is a country with a strong religious element in its citizenship. As many as $10 \%$ answered strongly disagree, where $5 \%$ or half came from among students. They argue that if they want to consume a product, they will still consume it because religion is forbidden, because they are not too religious.

There are 38\% agree that when consumers get a bad experience with Starbucks, they will stop buying Starbucks products, either wholly or at a particular outlet where they get the bad experience. Conversely, if they continue to have a good experience, will most likely continue to buy / consume products. It can also be seen that as many as $8 \%$ of respondents say that even if they get a bad experience they will continue to buy / consume Starbucks products due to loyalty or addictive taste to the product.

$38 \%$ agree that if they see that the behavior of employees who work at Starbucks, let alone the employees who serve them, then they will not buy a product in the same outlet. As many as $3 \%$ respondents strongly disagree, because there are still many employees who work in stores other than employees who behave so bad that they can just complain and then ask to be served by other employees.

\section{CONCLUSION}

When compared with previous studies, for example by Sari (2012) and Prastyo (2013), this study has a similar end result, that eWoM in Twitter has a significant effect on consumer buying interest.

Admin of @SbuxIndonesia is advised to increase the creativity and knowledge of its products, due to the value based on the results of the research, consumers have not so believe in the opinion of the Starbucks admin and have not felt the benefits of being followers of Twitter Starbucks. Admin may be able to increase social media-based promotions more creatively, due to the range of Starbucks consumers who are mostly aged 21-25.

Admin@SbuxIndonesia needs to improve the performance and behavior of employees to be better, because it can be seen the greatest influence is psychological, where bad employee behavior will make consumers do not buy Starbucks products in the same outlet.

Women more and more often use social media, is also more receptive in interacting with people who have not previously known through the internet / social media. In addition, men are more likely to choose another coffee shop that significantly sells coffee cheaper than Starbucks. and that Starbucks products are consumed more by younger age. Starbucks Starbucks products can be consumed by people of all ages, because many Starbucks products do not contain coffee and consumers may ask not to use too much sugar / cream so that small children and parents can consume the product and that Starbucks products are consumed more by younger age. 


\section{REFERENCES}

Arifin, Z (2011). Penelitian Pendidikan : Metode dan Paradigma Baru.Bandung:Remaja Rosdakarya.

Arikunto, Suharsimi (2006). Prosedur Penelitian Suatu Pendekatan Praktik, Ed Revisi VI, Penerbit PT Rineka Cipta, Jakarta. Bailey, Kenneth. D (1986). Methods of Social Research. Free Press: London $3^{\text {rd }}$ edition, Page 41.

Buttle, Francis Arthur / Williams, Martin (2014). Managing negative word-of-mouth:an exploratory study. Journal of Marketing Management Volume 30, Issue 13-14, 2014.

Cheung, Christy M. K. / Thadani, Dimple R. (2012). The Effectiveness of Electronic Word-of-Mouth Communication: A Literature Analysis. Journal Decision Support Systems archive Volume 53 Issue 1, April, 2012 Pages 218-225.

Chevalier, Judith A / Mayzlin, Dina (2006). The Effect of Word of Mouth on Sales: Online Book Reviews. Journal of Marketing ResearchVol. XLIII (August 2006), 345-354.

Davis, Fred D. (1989). Perceived usefulness, perceived ease of use, and user acceptance of information technology. MIS Quarterly September. Page 319-340.

Ghazali, Imam (2006). Aplikasi Analisis Multivarite dengan SPSS, CetakanKeempat. Badan Penerbit Universitas Diponegoro. Semarang. Hamidi. 2005. Metode Penelitian Kualitatif. Malang : UMM Press

Hennig-Thurau, Thorsten / Gwinner, Kevin P. / Walsh, Gianfranco / Gremler, Dwayne D. (2004). Electronic Word-of-Mouth Via Consumer-Opinion Platforms : What Motivates Consumers to Articulate Themselves on The Internet. Journal of Interactive Marketing / Volume 18 / Number 1 / Winter 2004.

Kaplan, Andreas M. / Haenlein, Michael (2010). Users of the world, unite! The challenges and opportunities of Social Media. Business Horizons Volume 53, Issue 1, January-February 2010, Pages 59-68.

Lamb, Charles W. / Hair, Joseph F. / McDaniel, Carl (2006). MKTG. Ohio: Thomson Higher Education.

Maslow, Abraham (1943). A Theory of Human Motivation. Wilder Publications, Incorporated, 2013 Psychology - 40 pages.

Sudjana, Nana / Ibrahim (2007). Penelitian dan Penilaian Pendidikan. Bandung. Sinar Baru Algensindo.

Sugiyono (2011). Metode Penelitian Kuantitatif, kualitatif dan R \& D. Bandung. Alfabeta.

Wijaya, Tommi / Paramita, Eristia Lidia (2014). Pengaruh Electronic Word of Mouth (eWoM) Terhadap Keputusan Pembelian Kamera DSLR. Seminar Nasional dan Call for Paper (Sancall 2014), Hlm: 12-19. 